University of Nebraska - Lincoln

DigitalCommons@University of Nebraska - Lincoln

Faculty Papers and Publications in Animal

Science

Animal Science Department

1973

\title{
Gain, Feed Conversion and Carcass Traits of Swine Fed Under Two Nutritional Regimes
}

\author{
P. J. Cunningham \\ University of Nebraska-Lincoln \\ T. E. Socha \\ University of Nebraska-Lincoln \\ E. R. Peo, Jr. \\ University of Nebraska-Lincoln \\ R. W. Mandingo \\ University of Nebraska-Lincoln
}

Follow this and additional works at: https://digitalcommons.unl.edu/animalscifacpub

Part of the Animal Sciences Commons

Cunningham, P. J.; Socha, T. E.; Peo, Jr., E. R.; and Mandingo, R. W., "Gain, Feed Conversion and Carcass Traits of Swine Fed Under Two Nutritional Regimes" (1973). Faculty Papers and Publications in Animal Science. 638.

https://digitalcommons.unl.edu/animalscifacpub/638

This Article is brought to you for free and open access by the Animal Science Department at DigitalCommons@University of Nebraska - Lincoln. It has been accepted for inclusion in Faculty Papers and Publications in Animal Science by an authorized administrator of DigitalCommons@University of Nebraska - Lincoln. 


\title{
GAIN, FEED CONVERSION AND CARCASS TRAITS OF SWINE FED UNDER TWO NUTRITIONAL REGIMES ${ }^{1}$
}

\author{
P. J. Cunningham, T. E. Socha, E. R. Peo, Jr. and R. W. Mandigo \\ University of Nebraska, Lincoln $68503^{2}$
}

\section{Summary}

$D^{2}$ ATA involving 505 Gene Pool boars, barrows and gilts and 126 Hampshire boars and gilts fed two nutritional diets were presented. One diet consisted of high lysine corn, minerals and vitamins (10\% protein) while the other diet was a $14 \%$ protein corn-soy diet.

Pigs fed the low protein diet gained slower and were fatter than pigs fed the $14 \%$ protein diet. In addition, kilograms of ham and loin/day of age was less for pigs on the low protein diet indicating a slower rate of lean growth. Carcasses from pigs fed the low protein diet had more backfat, less percent ham and loin and smaller loin eye area.

Sex differences between boars and gilts were obtained for daily gain and probe in the Gene Pools but not in the Hampshires. When barrows and gilts were compared, barrows grew faster and had smaller loin eye area than gilts. No significant differences between barrows and gilts were found for backfat, carcass length, kilograms of ham and loin/day of age or percent ham and loin.

A significant sex $\mathrm{x}$ diet interaction for daily gain was obtained for boars and gilts. Boars grew faster on the $14 \% \mathrm{C}-\mathrm{S}$ diet while gilts had the fastest growth rate on the $10 \% \mathrm{HL}$ diet indicating that boars require a higher level of dietary protein than gilts.

\section{Introduction}

For the past several decades, swine have routinely been fed diets containing corn and supplemental dietary protein. Therefore, natural and artificial selection have been operat-

1 Published with the approval of the Director as Paper No. 3455 Journal Series, Nebraska Agr. Exp. Sta. Research reported was conducted under Project 13-29.

2 Department of Animal Science. Acknowledgment is made to Alan Keetle and Robert Hageman for assistance in caring for the experimental animals, to Dawes Laboratories. Inc., Chicago and the American Cyanamid Co., Princeton, New Jersey, for the vitamins and antibiotics used in the experimental diets and to the Calcium Carbonate Co., Quincy, Illinois, for the trace minerals. ing within a relatively narrow range of nutritional environment. Present day pigs are undoubtedly the offspring of individuals which have performed acceptably under this narrow range of nutritional environment. Little work has been done to determine the effectiveness of selection under different nutritional environments. Fowler and Ensminger (1960) investigated the effect of selection for rate of gain under full and restricted feeding. When plant proteins and other sources of supplemental protein become limited for use in swine diets, it will be necessary to have or develop pigs which can perform acceptably on diets containing less supplemental protein than is presently being used.

The data presented represent the base population for an experiment designed to determine the adaptability and effectiveness of selection in populations under two different nutritional regimes.

\section{Materials and Methods}

Sixty-four Gene Pool (a synthetic involving 14 breeds and maintained as a closed population for five generations) and 39 Hampshire sows farrowed in September, 1971, providing pigs for initiation of an experiment involving selection for lean growth. Prior to weaning, pigs were randomly assigned within breed, litter and sex to one of three lines; (1) a line to be selected for lean growth and fed a $14 \%$ protein corn-soy diet (C-S), (2) a control line fed a $14 \%$ corn-soy diet (C-S), and (3) a line to be selected for lean growth and fed a diet containing only high lysine corn, minerals and vitamins (10\% protein) (HL). Composition of the two diets is given in table 1. In addition, 48 Gene Pool barrows and 48 Gene Pool gilts were randomly selected for carcass evaluation. These 96 pigs were from 55 different litters and included at least three pigs from each of the 25 Gene Pool sires used. No Hampshire pigs were selected for carcass evaluation due to poor reproductive performance of the Hampshire sows. 
TABLE 1. COMPOSITION OF THE DIETS

\begin{tabular}{|c|c|c|}
\hline Ingredient & $\begin{array}{c}14 \% \\
\text { corn soy } \\
\text { basal }\end{array}$ & $\begin{array}{l}10 \% \\
\text { high } \\
\text { lysine }\end{array}$ \\
\hline Normal corna & 83.65 & \\
\hline High lysine corn ${ }^{b}$ & & 95.95 \\
\hline $49 \%$ soybean meal & 12.45 & $\ldots \ldots$ \\
\hline Ground limestone & 0.45 & 0.25 \\
\hline \multicolumn{3}{|l|}{ Dicalcium phosphate } \\
\hline$(18.5 \% \mathrm{P})$ & 1.90 & 2.25 \\
\hline Salt (I) & 0.50 & 0.50 \\
\hline Trace minerals ${ }^{c}$ & 0.05 & 0.05 \\
\hline Vit.-AB mix ${ }^{d}$ & 1.00 & 1.00 \\
\hline
\end{tabular}

Normal corn $=$ No. 2 yellow, analyzed $9.5 \%$ protein; $0.31 \%$ lysine.

High lysine corn analyzed $10.5 \%$ protein; $0.51 \%$ lysine. c Composition (\%): $\mathrm{Mn}_{2} 5.5 ; \mathrm{Fe}, 10.0 ; \mathrm{Cu}, 1.1 ; \mathrm{Co}, 0.1$ I, $0.15 ; \mathrm{Zn}, 20$. Calcium Carbonate $\mathrm{C}_{0 .}$, Quincy, Illinois 1 Contributed the following vitamins and antibiotics per kilogram of diet: Vit. A, 2640 IU; Vit. Ds, 396 IU; riboflavin, $1.76 \mathrm{mg}$; pantothenic acid, $6.60 \mathrm{mg}$; niacin, $17.6 \mathrm{mg}$; choline $110 \mathrm{mg}$; Vit. $\mathrm{Br}_{12}, 11 \mathrm{mcg}$ and chlortetracycline-sulfamethazinepenicillin combination in a $1-1-.5$ ratio, 275 milligrams.

After weaning (42 days), boars and gilts were fed their respective diets until removed from test at approximately 79.4 kilograms. Pigs were probed when removed from test and probes were adjusted to $90.7 \mathrm{~kg}$ using an adjustment factor of $0.0224 \mathrm{~cm} /$ kilogram. The weight of $90.7 \mathrm{~kg}$ was chosen because parameter estimates used in the index construction were based on this weight. The feeding period was terminated after Gene Pool pigs had been on feed 150 days and Hampshires 175 days. Daily gains were calculated for all pigs, but any pig weighing less than $68 \mathrm{~kg}$ at the conclusion of the feeding period was not probed. An index value consisting of postweaning daily gain and adjusted probe was calculated $[I=100+28.66$ (Gain) -3.94 (Probe)]. The following parameter estimates for gain and probe were used in the index construction: relative economic weighting, 11.2 and -1.0 ; heritability, 0.33 and 0.40 ; standard deviation, $0.08 \mathrm{~kg}$ and $0.41 \mathrm{~cm} ; \mathrm{r}_{\mathrm{p}}=$ -.02 and $r_{\mathrm{g}}=-.20$. Gene Pool boars and gilts, on the HL diet initially, were transferred to the C-S diet after being removed from test. Boars not selected as replacements and weighing at least $68 \mathrm{~kg}$ at the conclusion of the feeding period were slaughtered at approximately 95.3 kilograms.

Gene Pool barrows and gilts, selected for carcass evaluation were started on test at an average weight of $19 \mathrm{~kg}$, were probed at approximately $79.4 \mathrm{~kg}$ and were slaughtered at an average weight of 97.5 kilograms. All pigs remained on their respective diets until slaughter. Daily gains were calculated for all pigs, but no probe, index or carcass data were ob- tained for pigs weighing less than $68 \mathrm{~kg}$ after 150 days on test. Feed conversion data were collected on a pen basis for the first 91 days of the feeding period and involved three pens of eight pigs for each sex-diet subclass.

The number of pigs evaluated for each of the traits and diets is presented in table 2. More pigs were evaluated on the C-S diet since in this initial generation there is no genetic difference between pigs designated as controls and those designated to be selected for leari growth on the C-S diet.

Gene Pool boars and gilts were fed in drylot ( 17 to 19 pigs per pen) at the Swine Research Center in Lincoln. Gene Pool barrows and gilts selected for carcass evaluation were fed in an environmental regulated building with slatted floor at the Field Laboratory at Mead. Five pigs in this group either died or had to be removed from test due to injury. Hampshire boars and gilts were fed in drylot at the Mead facility. Two pens were fed in each sexdiet subclass except for the $10 \%$ HL diet boars which were all fed in one pen. All carcass data was obtained at Wilson Certified Foods, Inc. in Omaha. Carcass length and backfat measurements were obtained from the hot carcass with ham and loin weights taken following a 24-hr. chill. The right loin from each careass was shipped to Lincoln where it was split at the 10th rib to obtain loin eye area.

The design for each group of data was a two-way crossclassified design with both factors considered fixed. Data were analyzed by analysis of variance procedures appropriate for data with unequal subclass numbers (Har-

TABLE 2, NUMBER OF PIGS EVALUATED FOR THE VARIOUS TRAITS AND DIETS

\begin{tabular}{|c|c|c|c|}
\hline Traits & Gain & Probe & $\begin{array}{c}\text { Carcass } \\
\text { data }\end{array}$ \\
\hline \multicolumn{4}{|l|}{ Gene Pool } \\
\hline $\begin{array}{l}14 \% \text { Boars } \\
14 \% \text { Gilts } \\
10 \% \text { Boars } \\
10 \% \text { Gilts }\end{array}$ & $\begin{array}{r}135 \\
140 \\
68 \\
71\end{array}$ & $\begin{array}{r}132 \\
138 \\
54 \\
67\end{array}$ & $\begin{array}{l}88 \\
\ddot{2} \\
\cdots\end{array}$ \\
\hline \multicolumn{4}{|l|}{ Gene Pool } \\
\hline $\begin{array}{l}14 \% \text { Barrows } \\
14 \% \text { Gilts } \\
10 \% \text { Barrows } \\
10 \% \text { Gilts }\end{array}$ & $\begin{array}{l}23 \\
24 \\
20 \\
24\end{array}$ & $\begin{array}{l}21 \\
23 \\
17 \\
18\end{array}$ & $\begin{array}{l}20 \\
20 \\
15 \\
13\end{array}$ \\
\hline \multicolumn{4}{|l|}{ Hampshire } \\
\hline $\begin{array}{l}14 \% \text { Boars } \\
14 \% \text { Gilts } \\
10 \% \text { Boars } \\
10 \% \text { Gilts }\end{array}$ & $\begin{array}{l}36 \\
43 \\
19 \\
28\end{array}$ & $\begin{array}{r}32 \\
41 \\
8 \\
16\end{array}$ & $\begin{array}{l}\cdots \\
\cdots \\
\cdots\end{array}$ \\
\hline
\end{tabular}

$14 \%$ corn-soy diet.

- $10 \%$ high lysine corn diet. 
vey, 1960). The three groups of data were analyzed separately due to the confounding which existed between group and location or group and management system. Cold carcass weight was used as a covariable in analyses involving carcass traits.

\section{Results and Discussion}

Average Daily Gain. Mean daily gains for the three groups are presented in table 3. Significant $(\mathrm{P}<.05)$ sex $\mathrm{x}$ diet interactions were obtained for both the Gene Pool and Hampshire boar and gilt data. Boars gained faster than gilts on the $14 \%$ C-S diet while gilts gained faster than boars when fed the $10 \% \mathrm{HL}$ diet. The $10 \% \mathrm{HL}$ diet reduced gains by 0.18 and $0.23 \mathrm{~kg} /$ day for boars compared to a reduction of 0.08 and $0.14 \mathrm{~kg} /$ day for gilts. The existence of this interaction indicates that boars require a higher level of dietary protein than gilts to support maximum growth potential.

Diet differences existed for both groups of boars and gilts $(\mathrm{P}<.001)$. In a comparison of boars and gilts fed 20 and $12 \%$ protein diets, Davey and Morgan (1969) reported pigs fed the $20 \%$ protein diet had a faster rate of growth. Gene Pool pigs fed the 14\% $\mathrm{C}-\mathrm{S}$ diet gained $0.13 \mathrm{~kg} /$ day faster than those fed the 10\% HL diet. For Hampshires, the difference was $0.18 \mathrm{~kg} /$ day in favor of the $14 \% \mathrm{C}$-S diet. The $10 \% \mathrm{HL}$ diet is apparently a suboptimal protein (or amino acid) diet for maximizing growth in swine. A decrease in growth rate occurred even though the lysine content of the $10 \% \mathrm{HL}$ diet was relatively

TABLE 3. PERFORMANCE OF PIGS FED $14 \%$ CORN-SOY AND $10 \%$ HIGH LYSINE DIETS

\begin{tabular}{|c|c|c|c|c|}
\hline \multirow[b]{2}{*}{ Trait } & \multicolumn{2}{|c|}{ Corn-soy $(14 \%)$} & \multicolumn{2}{|c|}{$\underset{\text { lysine }(10 \%)}{\text { High }}$} \\
\hline & Males & Females & Males & Females \\
\hline $\begin{array}{l}\text { Gene Pool: boars; gilts } \\
\text { Daily gain, kgabe } \\
\text { Probe, cmabc } \\
\text { Index abe }\end{array}$ & $\begin{array}{r}0.65 \\
3.15 \\
106.33\end{array}$ & $\begin{array}{r}0.62 \\
3.53 \\
104.19\end{array}$ & $\begin{array}{r}0.47 \\
3.89 \\
99.67\end{array}$ & $\begin{array}{r}0.54 \\
4.01 \\
100.07\end{array}$ \\
\hline $\begin{array}{l}\text { Gene Pool: barrows; gilts } \\
\text { Daily gain, kg ab } \\
\text { Probe, cma } \\
\text { Index }{ }^{a b} \\
\text { Efficiency, feed/gain a } \\
\text { Intake, kg ab }\end{array}$ & $\begin{array}{r}0.71 \\
3.48 \\
106.78 \\
3.22 \\
2.28\end{array}$ & $\begin{array}{r}0.65 \\
3.45 \\
105.05 \\
3.19 \\
2.06\end{array}$ & $\begin{array}{r}0.54 \\
4.01 \\
100.70 \\
3.86 \\
1.98\end{array}$ & $\begin{array}{r}0.46 \\
3.96 \\
99.20 \\
3.89 \\
1.77\end{array}$ \\
\hline $\begin{array}{l}\text { Hampshire; boars, gilts } \\
\text { Daily gain, } \mathrm{kg} \mathrm{ac}^{\mathrm{ac}} \\
\text { Probe, } \mathrm{cm}^{\mathrm{a}} \\
\text { Index } \mathrm{b}\end{array}$ & $\begin{array}{r}0.52 \\
2.49 \\
105.82\end{array}$ & $\begin{array}{r}0.48 \\
2.54 \\
104.20\end{array}$ & $\begin{array}{r}0.29 \\
3.50 \\
98.42\end{array}$ & $\begin{array}{r}0.34 \\
3.63 \\
97.17\end{array}$ \\
\hline
\end{tabular}

high $(0.5 \%)$. It should be noted, however, that some pigs performed acceptably on the $10 \% \mathrm{HL}$ diet. The standard deviation for pigs fed the $10 \%$ HL diet was larger than for pigs fed the $14 \%$ C-S diet $(0.12$ vs. $0.09 \mathrm{~kg} / \mathrm{day}$ for Gene Pools and 0.11 vs. $0.08 \mathrm{~kg} /$ day for Hampshires).

Sex differences were significant $(P<.025)$ for boars and gilts in the Gene Pool population, but not in the Hampshire population. Gene Pool boars gained slower than gilts $(0.56$ vs. $0.58 \mathrm{~kg} /$ day) while in the Hampshire population the gains were 0.40 and $0.41 \mathrm{~kg} /$ day. The large degrees of freedom within the Gene Pool population undoubtedly contributed to the statistical significance of the small difference in growth rate between the boars and gilts. Davey and Morgan (1969) found no difference in growth rate between boars and gilts.

Even though direct comparison of the two breeds is not possible due to the confounding with location, the redcution in growth rate was greater for Hampshires indicating the possibility of a greater protein requirement for this breed than for Gene Pool pigs. These Hampshire pigs could be classified as more meattype pigs (table 3) than the Gene Pools, suggesting that leaner pigs have a higher protein requirement. In addition, growth rate of the Hampshires was low even on the $14 \%$ C-S diet. Observations made during the feeding period suggested that the Hampshire pigs on the $14 \%$ diet did not begin to grow at an acceptable rate until they had reached approximately 56.7 kilograms. This observation suggests that even the $14 \% \mathrm{C}-\mathrm{S}$ diet may be suboptimal at light weights for meat-type pigs. However, Heldt and Lucas (1970) did not obtain any line $\mathrm{x}$ protein sequence interaction for barrows of the same genetic lines as those used in this study with protein sequences of 16 to $14 \%$ and 14 to $12 \%$.

No sex $\mathrm{x}$ diet interaction existed between barrows and gilts fed the two diets (table 3 ). However, barrows outgained gilts by 0.09 $\mathrm{kg} /$ day on the $10 \% \mathrm{HL}$ diet compared to 0.06 $\mathrm{kg} /$ day on the $14 \% \mathrm{C}-\mathrm{S}$ diet suggesting that gilts may require a higher level of dietary protein than barrows. As was true with the boar and gilt data, highly significant $(\mathrm{P}<$ .001 ) diet differences were obtained. Pigs fed the $14 \% \mathrm{C}-\mathrm{S}$ diet gained $0.18 \mathrm{~kg} /$ day faster than pigs fed the $10 \%$ HL diet. Numerous other workers have shown that increasing the level of dietary protein increases growth rate for barrows and/or gilts (Jensen et al., 1955; 
Baker et al., 1967; Clawson, 1967; Jurgens et al., 1967; Lee, McBee and Howath, 1967; Davey and Morgan, 1969). However, Gilster and Wahlstrom (1970) reported a reduction in gain of only $0.06 \mathrm{~kg} /$ day for pigs fed high lysine corn in a sequence of 12 to $10 \%$ protein compared to normal corn in a sequence of 16 to $14 \%$ protein.

A sex difference $(0.07 \mathrm{~kg} /$ day; $P<.025)$ existed between barrows and gilts with barrows growing at a faster rate. The difference in gain between barrows and gilts obtained in this study is in close agreement with the results of Bruner and Swiger (1968).

Adjusted Probe. Even though slower growing, pigs fed the $10 \% \mathrm{HL}$ diet were fatter $(\mathrm{P}<.001)$ than those fed the $14 \%$ C-S diet for all three groups (table 3 ). Some bias is probably present in these data since a higher percentage of the pigs fed the $10 \% \mathrm{HL}$ diet were not probed. Pigs which grew at an acceptable rate on the $10 \% \mathrm{HL}$ diet undoubtedly had a lower protein requirement and tended to be fatter. This point is at least partially illustrated by the larger diet difference $(1.04 \mathrm{~cm})$ found for Hampshires compared to Gene Pools $(0.58$ and $0.53 \mathrm{~cm})$ and the fact that, proportionately, fewer Hampshires were probed (table 2). It is doubtful that this explains the entire diet differences. Therefore, the data would indicate that pigs fed an inadequate level of dietary protein may have a higher ratio of fat to lean than pigs fed a higher level of dietary protein. Ashton et al. (1955) and Baker et al. (1967) found no effect of level of dietary protein on carcass backfat with protein levels at $2 \%$ intervals from 10 to 20 and 10 to $16 \%$, respectively. In contrast, when comparing 16 and $12 \%$ protein diets, Kropf et al. (1959) found pigs fed a $16 \%$ protein diet had less backfat.

Sex differences in backfat were obtained for the comparison of Gene Pool boars and gilts $(\mathrm{P}<.001)$. Gene Pool boars had an average of $0.25 \mathrm{~cm}$ less backfat than gilts. Omtvedt et al. (1967) also found boars had less probe backfat than gilts. The failure to obtain a similar sex difference among the Hampshires may be due to the more meat-type nature of these pigs. In addition, no significant sex difference was observed between the Gene Pool barrows and gilts. This is in contrast to results presented by Cahill et al. (1960), Bruner et al. (1958), Hale and Southwell (1967) and Bruner and Swiger (1968).

A significant $(\mathrm{P}<.05)$ sex $\mathrm{x}$ diet interaction was obtained for adjusted probe for the Gene
Pool boars and gilts. This is contrary to results obtained for Gene Pool barrows and gilts and Hampshire boars and gilts. This result may reflect more a large number of degrees of freedom or bias resulting from a higher percentage of the $10 \% \mathrm{HL}$ diet boars not being probed rather than an important biological result. Gilts were fatter than boars on both diets with the magnitude of the difference being greater on the $14 \%$ C-S diet $(0.38 v s .0 .15 \mathrm{~cm})$.

Index. An index involving daily gain and adjusted probe was used to evaluate the net merit of each pig for growth rate. The index gave positive attention to an increase in daily gain and negative attention to an increase in backfat thickness. Mean index values for the three different groups of pigs are presented in table 3. Sex effects were significant $(P<.025)$ for all three groups of data. Boars had a faster rate of lean growth than gilts. The higher index values for boars were a result of the boars being leaner than the gilts rather than faster growing. In contrast, barrows had a higher index than gilts because they had a greater rate of daily gain rather than less backfat.

The effect of level of dietary protein on rate of lean growth was highly significant $(\mathrm{P}<$ .001 ) for all three groups. Pigs fed the $14 \%$ $\mathrm{C}-\mathrm{S}$ diet had a faster rate of lean growth than pigs fed the $10 \%$ HL diet. These data indicate that the dietary level of protein can be very important in determining the rate of lean growth in swine.

The slow rate of growth for Gene Pool boars fed the $10 \% \mathrm{HL}$ diet resulted in a significant sex $x$ diet interaction $(\mathrm{P}<.01)$ for the index value.

Feed Conversion. The effect of level of dietary protein on feed efficiency was highly significant $(\mathrm{P}<.001)$. Pigs fed the $14 \% \mathrm{C}-\mathrm{S}$ diet had a feed efficiency of 3.20 compared to 3.87 for pigs fed the $10 \% \mathrm{HL}$ diet (table 3 ). Similar results have been reported by Baker et al. (1967) and Clawson (1967). The effect of sex and the sex $\mathrm{x}$ diet interaction were not significant for efficiency.

Pigs fed the $10 \% \mathrm{HL}$ diet consumed less feed per day $(\mathrm{P}<.005)$ than pigs fed the $14 \% \mathrm{C}-\mathrm{S}$ diet (1.87 vs. $2.17 \mathrm{~kg}$ ). The lower daily consumption by pigs fed the lower protein diet may be a partial explanation for their poorer efficiency. They apparently did not consume enough feed above maintenance to allow for maximum growth.

A comparison of efficiency and intake data on a weight constant basis instead of an age basis results in a slightly larger difference be- 
tween diets for efficiency (3.16 vs. 3.87) and a smaller difference for daily intake $(2.04 \mathrm{vs}$. $1.87 \mathrm{~kg}$ ). However, both differences are still significant $(\mathrm{P}<.01)$.

Carcass Data. A summary of carcass traits for Gene Pool boars on the two diets is presented in table 4. Significant diet differences $(\mathrm{P}<.005)$ were obtained for length, backfat, kilogram of ham and loin/day of age and loin eye area. Since all carcass traits were adjusted for differences in cold carcass weight, the fact that pigs fed the $14 \% \mathrm{C}-\mathrm{S}$ diet were leaner (3.33 vs. $3.96 \mathrm{~cm})$, produced greater kilogram of ham and loin/day of age (0.16 vs. 0.14) and had larger loin eye areas (31.94 vs. 24.52 $\mathrm{cm}^{2}$ ) indicate that these pigs had a smaller ratio of fat to lean than pigs fed the $10 \% \mathrm{HL}$ diet. Similar results were reported by Davey and Morgan (1969) who showed that boars fed a $20 \%$ protein diet had leaner carcasses than boars fed $12 \%$ protein. The difference in carcass length $(77.7$ vs. $76.4 \mathrm{~cm}$ for $14 \%$ $\mathrm{C}-\mathrm{S}$ and $10 \% \mathrm{HL}$, respectively) due to diets is probably of little biological importance. The $10 \% \mathrm{HL}$ protein diet may have retarded skeletal development slightly.

Analysis of the carcass data from Gene Pool barrows and gilts resulted in significant $(\mathrm{P}<.005)$ diet differences for backfat, $\mathrm{kg}$ of ham and loin/day of age, percent ham and loin and loin eye area. The mean differences (table 5) indicate that pigs fed the $14 \% \mathrm{C}-\mathrm{S}$ diet had leaner carcasses than pigs fed the $10 \%$ HL diet. Leaner carcass with increased levels of dietary protein have also been reported by Ashton et al. (1955), Baker et al. (1967), Lee et al. (1967) and Davey and Morgan (1969).

Sex differences existed $(\mathrm{P}<.025)$ only for loin eye area with gilts having a larger loin eye area than barrows. No significant sex xdiet interactions were obtained, although some nonactivity was present for kilograms of ham and loin/day of age and percent ham and loin

\section{TABLE 4. CARCASS CHARACTERISTICS OF BOARS FED 14\% CORN-SOY AND 10\% HIGH LYSINE DIETS *}

\begin{tabular}{lcc}
\hline Trait & Corn-soy & $\begin{array}{c}\text { High } \\
\text { lysine }\end{array}$ \\
\hline${\text { Length, } \mathrm{cm}^{\mathbf{b}}}_{\text {Backfat, cm }}^{\text {b }}$ & 77.7 & 76.4 \\
Kg ham and loin/day of age & 3.33 & 3.96 \\
$\%^{\mathrm{h}}$ ham and loin & 0.16 & 0.14 \\
Loin eye area, $\mathrm{cm}^{2 \mathrm{~b}}$ & 42.24 & 41.31 \\
\hline
\end{tabular}

a All traits adjusted for differences in carcass weight.

b Diet differences significant $(P<.005)$.
TABLE 5. CARCASS CHARACTERISTICS OF BARROWS AND GILTS FED 14\% CORN-SOY AND 10\% HIGH LYSINE DIETS ${ }^{*}$

\begin{tabular}{|c|c|c|c|c|}
\hline \multirow[b]{2}{*}{ Trait } & \multicolumn{2}{|c|}{$\begin{array}{c}\text { Corn- } \\
\text { soy }(14 \%)\end{array}$} & \multicolumn{2}{|c|}{$\begin{array}{c}\text { High } \\
\text { lysine }(10 \%)\end{array}$} \\
\hline & Barrows & Gilts & Barrows & Gilts \\
\hline $\begin{array}{l}\text { Length, } \mathrm{cm} \\
\text { Backfat, } \mathrm{cm}^{\mathrm{b}} \\
\mathrm{Kg} \text { ham and loin/ }\end{array}$ & $\begin{array}{c}76.4 \\
3.89\end{array}$ & $\begin{array}{l}77.5 \\
3.89\end{array}$ & $\begin{array}{c}76.2 \\
4.42\end{array}$ & $\begin{array}{c}76.7 \\
4.22\end{array}$ \\
\hline $\begin{array}{l}\text { day of age } \\
\% \text { ham and loin } \\
\text { Loin eye }\end{array}$ & $\begin{array}{r}0.15 \\
41.22\end{array}$ & $\begin{array}{r}0.16 \\
42.50\end{array}$ & $\begin{array}{r}0.14 \\
40.10\end{array}$ & $\begin{array}{r}0.14 \\
40.11\end{array}$ \\
\hline area, $\mathrm{cm}^{2 \mathrm{bc}}$ & 26.32 & 29.16 & 21.87 & 23.42 \\
\hline
\end{tabular}

a All traits adjusted for differences in carcass weight.

b Diet differences significant $(\mathrm{P}<.005)$

c Sex differences significant $(\mathrm{P}<.025)$.

$(\mathrm{P}<.10)$. Baker et al. (1967) indicated a tendency for a sex $x$ protein level interaction for percent lean cuts. Examination of the means results in the conclusion that the $10 \%$ HL diet is restricting the performance of gilts more than it is barrows. These results suggest that gilts may have a greater protein requirement than barrows.

Feeding pigs an inadequate amount of dietary protein (10\% HL) apparently results in the production of a greater proportion of fat to lean. If pigs are to produce lean tissue, then adequate amounts of protein (total or amino acids) must be supplied in the diet.

\section{Literature Cited}

Ashton, G. C., Kastelic, D. C. Acker, A. H. Jensen, H. M. Maddock, E. A. Kline and D. V. Catron. 1955. Different protein levels with and without antibiotics for growing-finshing swine: effect on carcass leanness. J. Anim. Sci. 14:82.

Baker, D. H., C. E. Jordan, W. P. Waitt and D. W. Gouwens. 1967. Effect of a combination of diethylstilbestrol and methyltestosterone, sex and dietary protein level on performance and carcass characteristics of finishing swine. J. Anim. Sci. 26:1059.

Bruner, W. H., V. R. Cahill, W. L. Robison and R. F. Wilson. 1958. Performance of barrow and gilt littermate pairs at the Ohio Swine Evaluation Station. J. Anim. Sci. 17:875.

Bruner, W. H. and L. A. Swiger. 1968. Effects of sex, season and breed on live and carcass traits at the Ohio Swine Evaluation Station. J. Anim. Sci. 27: 383.

Cahill, V. R., H. S. Teague, L. E. Kunkle, A. L. Moxon and E. A. Rutledge. 1960. Measurement of and ways of affecting sex-influenced performance of growing finishing swine. J. Anim. Sci. 19:1036.

Clawson, A. J. 1967. Influence of protein level, amino acid ratio and caloric density of the diet on feed intake and performance of pigs. J, Anim. Sci. 26:328.

Davey, R. J. and D. P. Morgan. 1969. Protein effect on growth and carcass composition of swine selected for high and low fatness. J. Anim. Sci. 28:831. 
Fowler, S. H. and M. E. Ensminger. 1960. Interactions between genotype and plane of nutrition in selection for rate of gain in swine. J. Anim. Sci. 19:434.

Gilster, K. E. and R. C. Wahlstrom. 1970. Highlysine corn in growing-finishing swine rations. Swine Day. South Dakota State Univ. A.S. Series 70-41:46.

Hale, O. M. and B. L. Southwell. 1967. Differences in swine performance and carcass characteristics because of dietary protein level, sex and breed. J. Anim. Sci. 26:341.

Harvey, W. R. 1960. Least-squares analysis of data with unequal subclass numbers. U.S.D.A. Pub. A.R.S. 20-8.

Heldt, J. D. and L. E. Lucas. 1970. Effect of hormone combination and protein level on performance and carcass traits in two genetic lines of swine. J. Anim. Sci. 31:203. (Abstr.).

Jensen, A. H., D. C. Acker, H. M. Maddock, G. C. Ashton, P. G. Homeyer, E. O. Heady and D. V.
Catron. 1955. Different protein levels with and without antibiotics for growing-finishing swine: effect on growth rate and feed efficiency. J. Anim. Sci. 14:69.

Jurgens, M. H., D. B. Hudman, C. H. Adams and E. R. Peo, Jr. 1967. Influence of a dietary supplement of lysine fed at two levels of protein on growth, feed efficiency and carcass characteristics of swine. J. Anim. Sci. 26:323.

Kropf, D. H., R. W. Bray, P. H. Phillips and R. H. Grummer, 1959. Effect of protein level and quality in swine rations upon growth and carcass development. J. Anim. Sci. 18:755.

Lee, C., J. L. McBee, Jr. and D. J. Howath. 1967. Dietary protein level and swine carcass traits. J. Anim. Sci. 26:490.

Omtvedt, I. T., D. F. Stephens, D. R. Rule and W. E. Sharp. 1967. Relationship between growth rate, probe backfat thickness and carcass traits in swine. Okla. Agr. Exp. Sta. MP-79:26. 